\title{
Genetic Differentiation of the Blue Swimming Crab Portunus pelagicus Along the Coastal Thai Waters Revealed by SSCP Analysis of Cytochrome c Oxidase Subunit I
}

\author{
Bavornlak Khamnamtong $^{1} \mathbb{D}$, Sirikan Prasertlux ${ }^{1} \mathbb{D}$, Sirithorn Janpoom ${ }^{1}$, , Sirawut \\ Klinbunga ${ }^{1, *}$ (iD
}

${ }^{1}$ Aquatic Molecular Genetic and Biotechnology Team, National Center for Genetic Engineering and Biotechnology (BIOTEC), National Science and Technology Development Agency (NSTDA), 113 Paholyothin Road, Khlong Nueng, Khlong Luang, Pathum Thani 12120, Thailand.

\section{How to cite}

Khamnamtong, B., Prasertlux, S., Janpoom, S., Klinbunga, S. (2021). Genetic Differentiation of the Blue Swimming Crab Portunus pelagicus Along the Coastal Thai Waters Revealed by SSCP Analysis of Cytochrome c Oxidase Subunit I. Genetics of Aquatic Organisms 5(2), 55-65. http://doi.org/10.4194/2459-1831-v5_2_02

\section{Article History}

Received 05 January 2021

Accepted 24 February 2021

First Online 03 March 2021

\section{Corresponding Author}

Tel.: +6626448150

E-mail: sirawut@biotec.or.th

\section{Keywords}

Portunus pelagicus

Genetic diversity

Population differentiation

SSCP

DNA sequences

\begin{abstract}
The basic information on genetic diversity and population structure is essential for the construction of appropriate management schemes leading to sustainable fisheries of the blue swimming crab (Portunus pelagicus). Here, genetic heterogeneity of $P$. pelagicus $(\mathrm{N}=174)$ was examined by single-strand conformational polymorphism (SSCP) analysis of mitochondrial cytochrome coxidase subunit I ( $\mathrm{PpCOI}_{270}$ ). Seven SSCP genotypes were found across all investigated samples. The average genetic distance between pairs of geographic samples was $0.0014-0.7247$. Significant geographic heterogeneity $(P<0.05)$ and restricted levels of female gene flow between paired samples (0.03-1.60 individuals per generation) were observed except between Chanthaburi - Prachuap Kriri Khan and Ranong - Krabi ( $>>0.05 ; 6.54$ and 16.17 individuals per generation) located in the same coastal regions. Therefore, the gene pool of $P$. pelagicus in Thai waters was genetically differentiated to different stocks even though it is biologically regarded as a potential dispersal species. Five geographic samples of $P$. pelagicus in Thai waters could be differentiated to three genetic stocks; Chanthaburi and Suratthani (stock A), Prachuap Khiri Khan (stock B) and Ranong and Krabi (stock C).
\end{abstract}

\section{Introduction}

The blue swimming crab, Portunus pelagicus is one of the commercially important species distributed from the eastern Mediterranean to east Africa in the Indian Ocean, and to Japan and Tahiti in the western and southern Pacific Ocean (Edgar 1990; Kailola et al. 1993). The information on intraspecific genetic diversity and population differentiation is essential for the construction of broodstock management schemes of this commercially important species (Avise 1994; Carvalho and Hauser 1994; Chai et al. 2017).
Genetic diversity of $P$. pelagicus in Australian waters was first reported based on allozyme analysis (Bryars and Adams 1999). Subsequently, Yap et al. (2002) isolated and characterized eight microsatellites in $P$. pelagicus and genetic polymorphism was examined in crabs collected covering the western seaboard of Australia. The mean observed heterozygosity $\left(H_{0}\right)$ at each locus was $0.30-0.78$. All loci did not deviate from Hardy-Weinberg expectations except at pPp05 where homozygote excess was observed.

Sezmis (2004) further investigated population genetic structure of Australian P. pelagicus collected 
from 16 different assemblages ( $N=4-57$ per each sample site) throughout the Australia waters using 6 microsatellite loci (pPp02, pPp04, pPp08, pPp09, pPp18 and pPp19) and cytochrome coxidase subunit I (COI, 342 bp) polymorphism. Significant differentiation of Australian $P$. pelagicus was found $\left(F_{S T}=0.098\right.$ for microsatellites and $\vartheta_{\mathrm{ST}}=0.375$ for $\mathrm{COI}$, respectively) with varying degrees of genetic heterogeneity.

Commercial aquaculture of $P$. pelagicus is successfully developed (Azra1 and Ikhwanuddin 2015). Accordingly, identification of genetic diversity and presently different crab stocks in Thai waters is essential as the first step for sustainable fisheries of $P$. pelagicus. This information is also important for the establishment of selective breeding programs and selection of appropriate broodstock leading to sustainable aquaculture of blue swimming crab in Thailand.

Genetic diversity of a small sample size of $P$. pelagicus in Thai waters (Ranong, Krabi, Chanthaburi, Prachuap Khiri Khan, and Suratthani; $N=72$ ) was reported based on amplified fragment length polymorphism (AFLP) (Klinbunga et al. 2007). The average genetic distance between samples across overall primers was $0.1151-0.2440$. Geographic heterogeneity analysis indicated statistically significant differences between all pairs of samples suggesting strong population subdivisions of Thai $P$. pelagicus (pairwise $\vartheta_{S T}=0.2480-0.4910 ; P<0.01$ ). In contrast, weak degrees of population subdivision were found in $P$. pelagicus in east and west coast areas of Peninsular Malaysia (mean $F_{\mathrm{ST}}=0.0413, N=87$ ) based on polymorphism of 4 microsatellite loci. Significant population differentiation was observed between each of the east coast populations (Terengganu, Negeri
Sembilan and Sarawak; $\mathrm{P}<0.05)$ but not between the west coast populations (Perak, and Johor; $P>0.05$ ) and among different coastal regions $(P>0.05)$ (Chai et al 2017). Therefore, intraspecific population structure of $P$. pelagicus in Thai-Malaysian peninsula need to be confirmed using larger sample sizes.

Single-strand conformational polymorphism (SSCP) is convenient and cost-effective for examining DNA polymorphism. The major advantage of SSCP is that a large number of individual could be simultaneously genotyped (Khamnamtong et al. 2005) and variations according to one or a few substitutions could be detected (Orita et al. 1989). Therefore, SSCP is one of the potential techniques for detection of genetic polymorphism at different taxonomic levels.

In this study, genetic diversity and intraspecific population differentiation of a larger sample size of $P$. pelagicus in Thai waters $(N=174)$ were determined using SSCP analysis of the mitochondrial $\mathrm{COI}$ gene segment. Genetic diversity within samples and differentiation between geographic samples were examined.

\section{Materials and Methods}

\section{Sampling}

The blue swimming crabs ( $P$. pelagicus) were livecaught from Chanthaburi $\left(12^{\circ} 35^{\prime} 60 \mathrm{~N} 102^{\circ} 9^{\prime} 0 \mathrm{E}, N=29\right)$, Prachuap Khiri Khan $\left(11^{\circ} 49^{\prime} 0 \mathrm{~N} 99^{\circ} 47^{\prime} 60 \mathrm{E}, \mathrm{N}=40\right)$ and Suratthani $\left(9^{\circ} 7^{\prime} 60 \mathrm{~N} 99^{\circ} 19^{\prime} 0 \mathrm{E}, N=35\right)$ located in the Gulf of Thailand and Ranong $\left(9^{\circ} 58^{\prime} 0 \mathrm{~N} 98^{\circ} 37^{\prime} 60 \mathrm{E}, N=35\right)$ and Krabi $\left(8^{\circ} 4^{\prime} 0 \mathrm{~N} 98^{\circ} 55^{\prime} \mathrm{O}, N=35\right)$ located in the Andaman Sea (Figure 1). Taxonomic identification of specimens

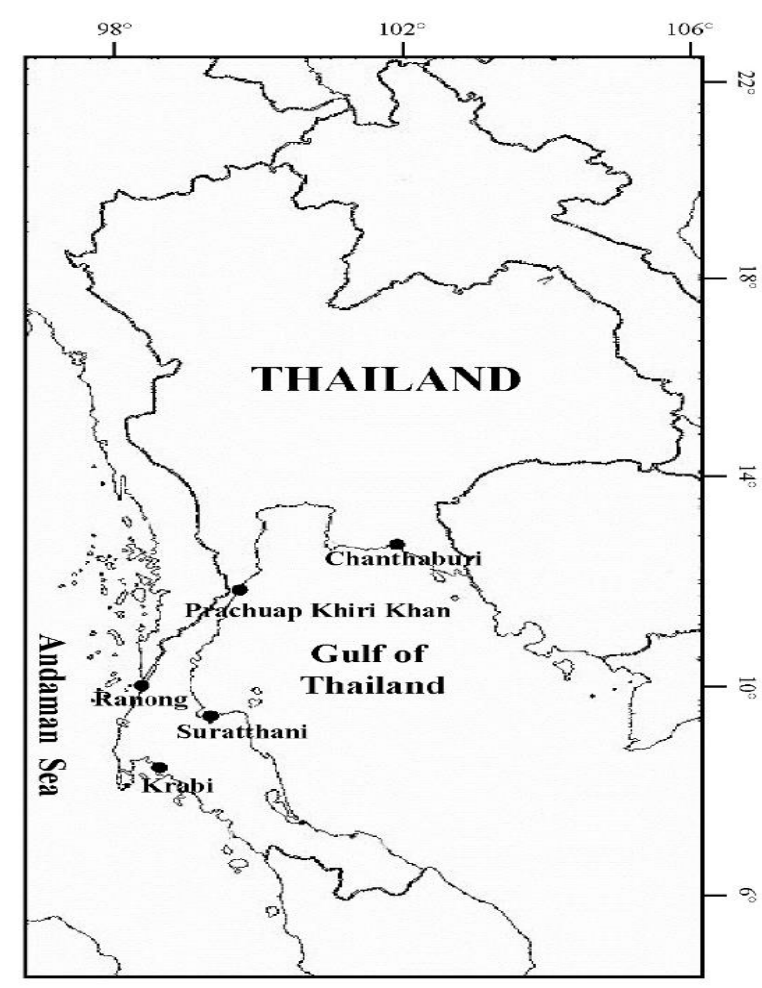

Figure 1. Sampling collection sites of $P$. pelagicus in this study. 
was performed following Lai et al. (2006). The whole specimens or muscle dissected out from the first pereiopod of each crab were kept at -30 ㄷ C until used.

\section{DNA Extraction}

Genomic DNA was extracted from the pereiopod muscle of each crab using a phenol-chloroformproteinase K method (Klinbunga et al. 1996). Briefly, the muscle tissue (20-30 mg) was placed in a mortar containing liquid $\mathrm{N}_{2}$ and ground to fine powder. The tissue powder was transferred to a centrifuge tube containing $500 \mu \mathrm{l}$ of the extraction buffer (100 mM Tris$\mathrm{HCl}, 100 \mathrm{mM}$ EDTA, $250 \mathrm{mM} \mathrm{NaCl}$; $\mathrm{pH}$ 8.0) and briefly homogenized with a micropestle. SDS (10\%) and RNase A $(10 \mathrm{mg} / \mathrm{ml})$ solutions were added to final concentrations of $1.0 \%(\mathrm{w} / \mathrm{v})$ and $100 \mu \mathrm{g} / \mathrm{ml}$, respectively. The resulting mixture was then incubated at $37^{\circ} \mathrm{C}$ for $1 \mathrm{~h}$. Subsequently, a proteinase $\mathrm{K}$ solution (10 $\mathrm{mg} / \mathrm{ml}$ ) was added to the final concentration of 300 $\mu \mathrm{g} / \mathrm{ml}$ and further incubated at $55^{\circ} \mathrm{C}$ for $3 \mathrm{~h}$. An equal volume of buffer-equilibrated phenol was added and gently mixed for $15 \mathrm{~min}$. The solution was centrifuged at $10,000 \mathrm{~g}$ for $10 \mathrm{~min}$ at room temperature. The upper aqueous phase was transferred to a new sterile microcentrifuge tube. This extraction process was repeated once with phenol and twice with chloroform: isoamyalcohlo (24:1). The aqueous phase was transferred into a sterile microcentrifuge. One-tenth volume of $3 \mathrm{M}$ sodium acetated, $\mathrm{pH} 5.2$ was added. DNA was precipitated by an addition of two volumes of prechilled absolute ethanol and mixed thoroughly. The mixture was incubated at $-80^{\circ} \mathrm{C}$ for $30 \mathrm{~min}$. The precipitated DNA was washed twice with $1 \mathrm{ml}$ of $70 \%$ ethanol (10 $\mathrm{min}$ each). After centrifugation, the supernatant was removed. The DNA pellet was air-dried and resuspended in 30-50 $\mu \mathrm{l}$ of TE buffer (10 mM Tris$\mathrm{HCl}$ and $0.1 \mathrm{mM}$ EDTA, $\mathrm{pH}$ 8.0). The DNA solution was incubated at $37^{\circ} \mathrm{C}$ for $1-2 \mathrm{~h}$ and kept at $4^{\circ} \mathrm{C}$ for immediately used or stored at $-20^{\circ} \mathrm{C}$ for long storage.

\section{Amplification of 18S, $12 S$ and 165 Ribosomal (r) DNAs and NADH Dehydrogenase Subunit 5 (ND5), Cytochrome c Oxidase Subunits I and II (COI-COII) and COI}

Universal primers for amplification of 185 rDNA (Klinbunga et al. 2003), COI (Folmer et al. 1994), COICOIl (Sihanuntavong et al. 1999), and 12S rDNA, 16S rDNA and ND5 (Small and Chapman 1997) were tested. The amplification reaction was performed in a reaction volume of $25 \mu$ l contained $75 \mathrm{mM}$ Tris- $\mathrm{HCl}(\mathrm{pH} 8.8$ at $\left.25^{\circ} \mathrm{C}\right), 20 \mathrm{mM}\left(\mathrm{NH}_{4}\right)_{2} \mathrm{SO}_{4}, 0.1 \%$ Tween $20,1.5-2.0 \mathrm{mM}$ $\mathrm{MgCl}_{2}, 200 \mu \mathrm{M}$ each dATP, dTTP, dCTP and dGTP, 0.25$0.5 \mu \mathrm{M}$ each primer, 1 unit Taq DNA polymerase (Fermentus) and 50 ng genomic DNA. PCR was carried out using conditions described in Khamnamtong et al. (2005). Five microliters of the PCR product was sizefractionated through a $1 \%$ agarose gel to determine whether the amplification reaction was successful.

\section{Cloning of the Amplified COI and 12S rDNA Gene Segment}

The amplified COI and 12S rDNA (706 and $406 \mathrm{bp)}$ fragments were reamplified with the original primers and size-fractionated through a $1.5 \%$ agarose gel and excised. The electrophoresed fragment was eluted from the gel using a Hiyield ${ }^{\mathrm{TM}}$ Gel Extraction Kit following the protocol recommended by the manufacturer (Real Genomics). The eluted DNA was ligated to pGEM-T easy vector (Promega) in a total volume of $10 \mu$ containing 3 $\mu \mathrm{l}$ of the gel-eluted PCR product, $25 \mathrm{ng}$ of $\mathrm{pGEM}^{\oplus}$-T easy vector, $5 \mu \mathrm{l}$ of $2 \mathrm{X}$ rapid ligation buffer $(60 \mathrm{mM}$ Tris- $\mathrm{HCl}$ $\mathrm{pH}$ 7.8, $20 \mathrm{mM} \mathrm{MgCl}$, $20 \mathrm{mM}$ DTT, 2 mM ATP and $10 \%$ PEG 8000) and 3 Weiss units of T4 DNA ligase. The ligation mixture incubated at $4^{\circ} \mathrm{C}$ for $16 \mathrm{~h}$. One-tenth volume of each ligation was electrotransformed to Eschericha coli JM109 (Dower et al., 1988). Recombinant clones were selected by the lac $Z$ system following standard protocols (Sambrook and Russell 2001). Briefly, the mixture was incubated on ice for $30 \mathrm{~min}$. The cells were heat-shock for $45 \mathrm{~s}$ at $42^{\circ} \mathrm{C}$ in a water bath without shaking. The tube was returned immediately to ice for $5 \mathrm{~min}$. The cells transformed with ligation reactions were transferred to the tube containing $1 \mathrm{ml}$ of room temperature SOC medium (2\% Bacto tryptone, $0.5 \%$ Bacto yeast extract, $10 \mathrm{mM} \mathrm{NaCl}, 2.5 \mathrm{mM} \mathrm{KCl}, 10$ $\mathrm{mM} \mathrm{MgCl}_{2}, 10 \mathrm{mM} \mathrm{MgSO}_{4}$ and $20 \mathrm{mM}$ glucose). The cell suspension was incubated with shaking at $37^{\circ} \mathrm{C}$ for 90 min before centrifuged at $6,000 \mathrm{~g}$ for $1 \mathrm{~min}$ at room temperature. The pellet was gently resuspended in 100 $\mu \mathrm{l}$ of SOC medium and spread on a LB agar plate ( $1 \%$ Bacto-tryptone, $0.5 \%$ Bacto-yeast extract, $1.0 \% \mathrm{NaCl}$ and $1.5 \%$ agar) containing $50 \mu \mathrm{g} / \mathrm{ml}$ of ampicillin, 25 $\mu \mathrm{g} / \mathrm{ml}$ of IPTG and $20 \mu \mathrm{g} / \mathrm{ml}$ of X-gal. The spread agar plate was further incubated at $37^{\circ} \mathrm{C}$ overnight. The colonies containing inserted DNA are white while those without inserted DNA are blue.

\section{Plasmid DNA Extraction and Sequencing of Recombinant Clones}

Recombinant plasmids containing inserted DNA were extracted using a Plasmid Mini Kit (ATP Biotech Inc.). A recombinant clone was inoculated into $3 \mathrm{ml}$ of LB broth ( $1 \%$ tryptone, $0.5 \%$ yeast extract, $1.0 \% \mathrm{NaCl}$ ) containing $50 \mu \mathrm{g} / \mathrm{ml}$ of ampicillin and incubated at $37^{\circ} \mathrm{C}$ with constant shaking at $250 \mathrm{rpm}$ overnight. The culture was transferred into $1.5 \mathrm{ml}$ microcentrifuge tube and centrifuged at $12,000 \mathrm{~g}$ for $1 \mathrm{~min}$. The supernatant was discarded. The bacterial cell pellet was collected and resuspended with $200 \mu \mathrm{l}$ of the PD1 buffer containing RNaseA and thoroughly mixed by vortexed. The resuspended cells were lysed by the addition of $200 \mu \mathrm{l}$ of the PD2 buffer and mixed gently by inverting the tube 10 times. The mixture was left for $2 \mathrm{~min}$ at room temperature. Subsequently, $300 \mu$ of the buffer PD3 
was added to neutralize the alkaline lysis step and mixed immediately by inverting the tube for 10 times. To separate the cell debris, the mixture was centrifuged at $12,000 \mathrm{~g}$ for $15 \mathrm{~min}$. The supernatant was transferred into a collection tube containing the PD column and centrifuged at $6,000 \mathrm{~g}$ for $1 \mathrm{~min}$. The flow-through was discarded. The PD column was placed back in the collection tube. The column was washed by adding 400 $\mu \mathrm{l}$ of the W1 buffer and centrifuged at $6,000 \mathrm{~g}$ for $1 \mathrm{~min}$. After discarding the flow-through, $600 \mu$ lof the ethanoladded Wash buffer was added and centrifuged as above. The flow-through was discarded. The spin tube was centrifuge for an additional $2 \mathrm{~min}$ at $12,000 \mathrm{~g}$ to remove the residual Wash buffer. The dried PD column was placed in a new $1.5 \mathrm{ml}$ microcentrifuge tube and 30 $50 \mu$ of the Elution buffer or water was added at the center of the column to elute the extracted plasmid DNA. The column was left at room temperature for 2 $\min$ and centrifuge at $12,000 \mathrm{~g}$ for $2 \mathrm{~min}$. The concentration of extracted plasmid DNA was spectrophotometrically measured. The insert size of each recombinant plasmid was examined by digestion of the plasmid with Eco RI. The digest was carried out in a $15 \mu$ containing $1 \mathrm{X}$ restriction buffer $(90 \mathrm{mM}$ Tris- $\mathrm{HCl}$; $\mathrm{pH} 7.5,10 \mathrm{mM} \mathrm{NaCl}$ and $50 \mathrm{mM} \mathrm{MgCl}$ ), $1 \mu \mathrm{g}$ of recombinant plasmid and 3 units of Eco RI. The reaction was incubated at $37^{\circ} \mathrm{C}$ for $3-4 \mathrm{~h}$ before analyzed by agarose gel electrophoresis. Nucleotide sequences of recombinant plasmids were examined in both directions by automated DNA sequencer using M13 forward and/or M13 reverse primer as the sequencing primer. Inserted sequences were compared with those previously deposited in GenBank using BlastN (Altschul et al. 1990). Multiple sequence alignments were performed using Clustal W (Thompson et al, 1994).

\section{Primer Design, PCR and SSCP Analysis}

A pair of primers was designed from the amplified COI sequence and initially tested against genomic DNA of a representative individual from each geographic sample $(N=5)$. A PpCOI 270 marker derived from the $\mathrm{COI}$ gene segment of $P$. pelagicus (primers $\mathrm{PpCOI}_{270} \mathrm{~F}$ : $5^{\prime}-$ TTCAGCAGCCATCGCTCAC-3' and PpCOI $270-\mathrm{R}$ : 5'AGGGTCAAAGAATGAAGTAT-3'), was used for population genetic studies of $P$. pelagicus $(N=174$,
Table 1). PCR was performed composing of predenaturation at $94^{\circ} \mathrm{C}$ for $3 \mathrm{~min}$ followed by 35 cycles of denaturation at $94^{\circ} \mathrm{C}$ for $1 \mathrm{~min}$, annealing at $53^{\circ} \mathrm{C}$ for $1 \mathrm{~min}$, and extension at $72^{\circ} \mathrm{C}$ for $1 \mathrm{~min}$. The final extension was performed at $72^{\circ} \mathrm{C}$ for $7 \mathrm{~min}$. Five microliters of the product was mixed with 4 volumes of the loading dye (95\% formamide, $0.25 \%$ bromophenol blue, $0.25 \%$ xylene cyanol and $10 \mathrm{mM} \mathrm{NaOH}$ ), denatured at $95^{\circ} \mathrm{C}$ for $5 \mathrm{~min}$, immediately cooled on ice for $3 \mathrm{~min}$ and electrophoretically analyzed through $15.0 \%$ nondenaturing polyacrylamide gels (37.5:1 crosslink) at $12.5 \mathrm{~V} / \mathrm{cm}$ for $16 \mathrm{~h}$ at $4^{\circ} \mathrm{C}$.

SSCP bands were visualized by silver staining following a modification of the protocol described for SILVER SEQUENCE ${ }^{\mathrm{TM}}$ DNA Sequencing System (Promega). After electrophoresis, the gel plates were carefully separated apart. The long glass plate with the electrophoresed gel was placed in a plastic tray containing $1.5 \mathrm{I}$ of the fix/stop solution (10\% glacial acetic acid) and agitated well for 25-30 $\mathrm{min}$. The gel was briefly soaked in deionized water three times for $3 \mathrm{~min}$ each with shaking. The gel was transferred to $0.1 \%$ silver nitrate solution (1.5 I) and incubated with agitation at room temperature for $30 \mathrm{~min}$. The gel was soaked in 1.5 I of deionized water with shaking (10 forward and 10 backward steps) and immediately placed in the tray containing $1.5 \mathrm{I}$ of the chilled developing solution (chilled $0.03 \%$ sodium carbonate, $2.25 \mathrm{ml}$ of formaldehyde and $300 \mu \mathrm{l}$ of $10 \mathrm{mg} / \mathrm{ml}$ sodium thiosulfate). The gel was well agitated until the first bands are visible (1.5-2 $\mathrm{min}$ ) and transferred to another tray containing 1.5 I of chilled developer and shaken until bands from all examined samples were observed (2-3 min). One liter of the fix/stop solution was directly added to the developing solution and continued shaking for 3 min each. The gel was placed in the plastic bag and air-dried.

\section{Sequence Polymorphism of Different SSCP Genotypes of $\mathrm{PpCOI}_{270}$}

The PCR product of representative individuals of $P$. pelagicus exhibiting different SSCP genotypes of $\mathrm{PpCOI}_{270}$ ( $\mathrm{N}=2$ each except genotype $\mathrm{VI}$ which was found in only one individual) was gel-eluted and directsequenced for both directions. Nucleotide sequences of

Table 1. SSCP genotypes resulted from analysis of $\mathrm{PpCOI}_{270}$, of $P$. pelagicus originating from different geographic locations in Thai waters

\begin{tabular}{|c|c|c|c|c|c|c|}
\hline \multirow[t]{2}{*}{ SSCP genotype } & \multicolumn{3}{|c|}{ Gulf of Thailand } & \multicolumn{2}{|c|}{ Andaman Sea } & \multirow{2}{*}{$\begin{array}{c}\text { Total } \\
(\mathrm{N}=174)\end{array}$} \\
\hline & $\begin{array}{c}\mathrm{CHN} \\
(\mathrm{N}=29)\end{array}$ & $\begin{array}{c}\text { PKK } \\
(\mathrm{N}=40)\end{array}$ & $\begin{array}{c}\text { SUT } \\
(\mathrm{N}=35)\end{array}$ & $\begin{array}{c}\text { RNG } \\
(\mathrm{N}=35)\end{array}$ & $\begin{array}{c}\text { KRB } \\
(\mathrm{N}=35)\end{array}$ & \\
\hline 1 & 27 & 15 & 26 & - & 2 & 70 \\
\hline II & - & 4 & - & - & - & 4 \\
\hline III & - & 18 & - & 34 & 31 & 83 \\
\hline IV & - & - & 2 & - & 1 & 3 \\
\hline V & 1 & 1 & 7 & 1 & 1 & 11 \\
\hline VI & 1 & - & - & - & - & 1 \\
\hline VII & - & 2 & - & - & - & 2 \\
\hline
\end{tabular}

Abbreviations: $\mathrm{CHN}=$ Chanthaburi, $\mathrm{PKK}=$ Prachuap Kriri Khan, $\mathrm{SUT}=$ Suratthani, $\mathrm{RNG}=$ Ranong, $\mathrm{KRB}=\mathrm{Krabi}$ 
different SSCP genotypes were multiple aligned using Clustal W (Thompson et al., 1994). An unrooted maximum parsimony network was constructed from sequence polymorphism between different genotypes of $\mathrm{PpCOI} 270$.

\section{Data Analysis}

The gene diversity (Nei 1987) was estimated for each geographic sample. Unbiased genetic distance between pairs of geographic samples was determined (Nei 1978). Genetic heterogeneity in allele distribution frequencies between compared geographic samples was examined using the exact test. The $F_{\text {ST-based }}$ statistics $(\vartheta)$ between pairs of geographic samples, bootstrapping 10000 iterations to generate the $95 \%$ confidence interval, was estimated. The chi-square value was calculated and tested to determine whether $\vartheta$ was statistically different from zero (Weir and

Cockerham 1984) using $\quad \chi^{2}=2 N \vartheta(k-1)$ and $d f=(k-1)(s-1)$ where $N=$ number of investigated individuals, $k=$ number of allele per locus and $s=$ number of geographic samples. Population genetic parameters described above were computationally analyzed by TFPGA (Miller 1997). Female genetic exchanges among populations per generation were estimated using $N_{\mathrm{ef}} m=(1-\vartheta / 2 \vartheta)$. A UPGMA dendrogram (Sneath and Sokal 1973 was constructed to illustrate the relationships among geographic samples using PHYLIP (Felsenstein 1993).

\section{Results}

\section{Development of DNA Markers for Population Genetic Studies of $\boldsymbol{P}$. Pelagicus}

Primers for 185 rDNA, COI-COII, 165 rDNA and ND5 did not generate the amplification products against genomic DNA of representative individuals of blue swimming crabs ( $N=3$ for each geographic samples). Two primer pairs ( $\mathrm{COI}$ and $12 \mathrm{~S}$ rDNA) provided positive amplification products of 706, and $406 \mathrm{bp}$, respectively. Nucleotide sequences of the amplified fragments significantly matched $\mathrm{COI}$ of $P$. pelagicus voucher MaPrt001 ( $E$-value $=0.0)$ and $12 S$ rDNA of $P$. pelagicus voucher flh040815A ( $E$-value=0.0). A pair of primers was designed from each sequence and tested against genomic DNA of wild $P$. pelagicus. However, low polymorphism of $12 S$ rDNA was found following SSCP analysis (data not shown). Therefore, only COI (hereafter called $\mathrm{PpCO}_{270}$ ) which was consistently amplified and showed relatively high polymorphism was further used for population genetic analysis.

\section{Polymorphism of $\mathrm{PpCOI}_{270}$ Revealed by SSCP Analysis}

A total of 7 SSCP genotypes of $\mathrm{PpCOI}_{270}$ were found from SSCP analysis (Figure $2 A$ and Table 1). SSCP genotypes I predominated in crabs from the Gulf of Thailand (68/104 accounting for $65.38 \%$ ). This genotype was found in only two individual of the Andaman samples $(2 / 70,2.86 \%)$. In contrast, the genotype III was found in 65 individuals $(92.86 \%)$ of the Andaman samples but it was observed in only 18 individuals of P. pelagicus from Prachuap Khiri Khan (17.31\% of the Gulf of Thailand samples). The genotype VI was found in a single individual from Chanthaburi while genotypes II and VII were found only in $P$. pelagicus originating from Prachuap Kriri Khan ( $N=4$ and 2$)$.

The $\mathrm{PpCOI}_{270}$ gene segment of $P$. pelagicus exhibiting each SSCP genotype was sequenced $(N=2$ except genotype $\mathrm{VI}$ ). Nucleotide sequences were aligned and indicated that different SSCP genotypes of each marker can be distinguished by one or a few substitutions (Figure 2B). A maximum parsimony network based on $\mathrm{PpCOI}_{270}$ sequence polymorphism indicated 3 lineages of genotypes (A, B and C; Figure $3 A$ ). The blue swimming crab from Ranong (west) possessed the lineage B genotypes (1.000). The distributions of lineages A and B overlapped in the remaining geographic samples with different proportions. The highest frequency of lineage A genotypes was observed in Chanthaburi (0.931) followed by Suratthani (0.743), Prachuap Khiri Khan (0.475), and Krabi (0.057). The distribution of lineage $B$ genotypes in a particular sample was in the opposite direction. The genotype VII, an only member of lineage $C$, was found in 2 individuals of $P$. pelagicus from Prachuap Khiri Khan (Figure 3B).

\section{Genetic Diversity and Population Differentiation of $\boldsymbol{P}$. pelagicus in Thai Waters}

The average gene diversity in each and overall geographic sample were 0.0063 (Ranong)-0.2847 (Prachuap Kriri Khan) and 0.2860. The genetic distance between pairs of geographic samples was 0.0014 (between Ranong and Krabi; west coastal samples)0.7247 (between Chanthaburi and Ranong located in different coastal regions; Table 2).

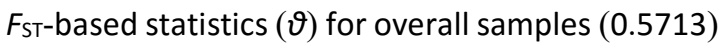
and paired geographic samples (0.0710-0.9357) bootstrapped overall loci was statistically significant $(P<0.05)$. Similar differentiation was also observed between all pairwise comparisons of $P$. pelagicus sample except between Ranong-Krabi ( $P>0.05)$ following $\chi^{2}$ analysis $(P<0.001)$ Geographic differentiation was observed across overall samples and between almost all of the paired samples $(P<0.0001)$ except between Chanhaburi-Prachuap Khiri Khan and Ranong-Krabi ( $>>0.05, \quad$ Table 3). Accordingly, investigated samples could be differentiated to three genetic stocks including Chanthaburi and Suratthani ( $\operatorname{stock}$ A), Prachuap Khiri Khan (stock B) and Ranong and Krabi (stock C).

The estimated female gene flow levels of Thai $P$. pelagicus in this study were $0.03-16.67$ individuals per generation. The levels between different genetic stocks were less than 1.60 individuals per generation which was lower than those within the same stocks 
A

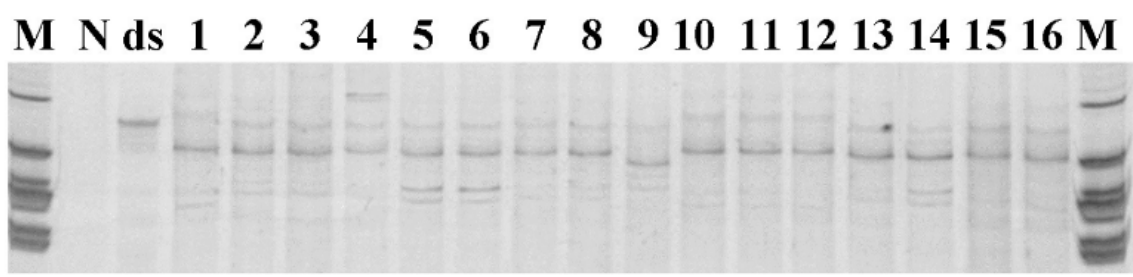

B

PP-COI270_I TTCAGCAGCCATCGCTCACGCAGGAGCTTCTGTAGATCTAGGTATTTTCTCTTTACATCT PP-COI270_II TTCAGCAGCCATCGCTCACGCAGGAGCTTCTGTAGATCTAGGTATTTTCTCTTTACATCT PP-COI270_II ITCAGCAGCCATCGCTCACGCAGGAGCTTCTGTAGATCTAGGTATTTTCTCTTTACATCT PP-COI270_IV TTCAGCAGCCATCGCTCACGCAGGAGCTTCTGTAGATCTAGGTATTTTCTCTTTACATCT PP-COI270_V TTCAGCAGCCATCGCTCACGCAGGAGCTTCTGTAGATCTAGGTATTTTCTCTTTACATCT PP-COI 270 VI TTCAGCAGCCATCGCTCACGCAGGAGCTTCTGTAGATCTAGGTATTTTCTCTTTACATCT PP-COI 270_VII TTCAGCAGCCATCGCTCACGCAGGAGCTTCTGTAGATCTAGGTATTTTCTCTTTACATCT PP-COI270 I GGCAGGTGTTTCCTCTATTTTAGGTGCAGTAAATTTCATGACCACCGTTATTAACATGCG PP-COI270- II AGCAGGTGTTTCCTCTATTTTAGGTGCAGTAAATTTCATGACCACCGTTATTAACATGCG PP-COI270-III GGCAGGTGTTTCCTCTATTCTAGGTGCAGTAAATTTCATGACCACCGTTATTAACATGCG PP-COI270_IV GGCAGGTGTTTCCTCTATTCTAGGTGCAGTAAATTTCATGACCACCGTCATTAACATGCG PP-COI270_V GGCAGGTGTTTCCTCTATTCTAGGTGCAGTAAATTTCATGACCACCGTTATTAACATGCG PP-COI270-VI GGCAGGTGTTTCCTCTATTCTAGGTGCAGTAAATTTCATGACCACCGTTATTAACATGCG PP-COI270_VII AGCAGGTGTTTCCTCTATTTTAGGTGCAGTAAATTTCATAACCACCGTTATTAACATACG

PP-COI270_I ATCTTTTGGTATAAGAATGGACCAAATACCATTATTCGTTTGATCAGTTTTTATCACTGC PP-COI270-II ATCTTTTGGTATAAGAATGGACCAAATACCATTATTCGTTTGATCAGTTTTTATCACTGC PP-COI270-II ITCTTTTGGTATAAGAATAGACCAAATGCCATTATTCGTTTGATCAGTATTTATCACTGC PP-COI270 IV ATCTTTTGGTATAAGAATGGACCAAATGCCATTATTCGTTTGATCAGTATTTATCACTGC PP-COI $270^{-} \mathrm{V}$ ATCTTTTGGTATAAGAATGGACCAAATGCCATTATTCGTTTGATCAGTATTTATCACTGC PP-COI270_VI GTCTTTTGGTATAAGAATGGACCAAATGCCATTATTCGTTTGATCAGTATTTATCACTGC PP-COI270-VII ATCTTTTGGTATAAGAATGGACCAAATGCCATTATTCGTTTGATCAGTATTTATCACTGC

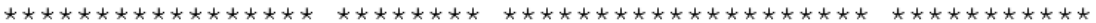

PP-COI270 I TATTCTTCTACTTTTATCTCTCCCTGTTCTTGCTGGAGCTATTACTATACTTCTTACAGA PP-COI270_II TATTCTTCTACTTTTATCTCTCCCTGTTCTTGCTGGAGCTATTACTATACTTCTTACAGA PP-COI $270^{-}$II I TATTCTTCTACTTTTATCTCTCCCTGTTCTTGCTGGAGCTATTACTATACTTCTTACAGA PP-COI270_IV TATTCTTCTACTTTTATCTCTCCCTGTTCTTGCTGGAGCTATTACTATACTTCTTACAGA PP-COI $270^{-} \mathrm{V}$ TATTCTTCTACTTTTATCTCTCCCTGTTCTTGCTGGAGCTATTACTATACTTCTTACAGA PP-COI270_VI TATTCTTCTACTTTTATCTCTCCCTGTTCTTGCTGGAGCTATTACTATACTTCTTACAGA PP-COI270-VII TATTCTTCTACTTTTATCTCTCCCTGTTCTTGCTGGAGCTATTACTATACTTCTTACAGA

PP-COI270 I CCGAAATCTAAATACTTCATTCTTTGACCCT PP-COI270-II CCGAAATCTAAATACTTCATTCTTTGACCCT PP-COI $270^{-}$III CCGAAATCTAAATACTTCATTCTTTGACCCT PP-COI270_IV CCGAAATCTAAATACTTCATTCTTTGACCCT $\mathrm{PP}-\mathrm{COI} 270^{-} \mathrm{V} \quad \mathrm{CCGAAATCTAAATACTTCATTCTTTGACCCT}$ PP-COI270-VI CCGAAATCTAAATACTTCATTCTTTGACCCT PP-COI270_VII CCGAAATCTAAATACTTCATTCTTTGACCCT

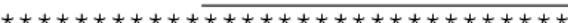

Figure 2. (A) Examples of SSCP patterns of $P p C O I_{270}$ of $P$. Pelagicus originating from Ranong (lanes 1-8), Suratthani (lanes 9-12), Krabi (lanes 13-16). Lane M, N and ds are a 100 bp DNA marker, the negative control (without genomic DNA template) and the non-denatured PCR product, respectively. (B) Nucleotide sequences of $P$. pelagicus representing seven SSCP genotypes of $\mathrm{PpCOI}_{270}$. The location and sequence of a forward primer and those complementary to a reverse primer are underlined. Variants at polymorphic sites are highlighted.

Table 2. Pairwise Nei's (1978) genetic distance (below diagonal) between pairs of geographic samples and gene diversity (diagonal) within samples of Thai $P$. pelagicus based on SSCP analysis of $\mathrm{PpCOI}_{270}$

\begin{tabular}{lccccc}
\hline \multicolumn{7}{c}{ CHN } & PKK & SUT & RNG & KRB \\
\hline CHN & 0.0667 & & & & \\
PKK & 0.1926 & 0.2847 & & & \\
SUT & 0.0124 & 0.1099 & 0.1947 & 0.0063 & 0.0898 \\
RNG & 0.7247 & 0.1105 & 0.5002 & 0.0014 & \\
KRB & 0.6220 & 0.0814 & 0.4243 & & \\
\hline
\end{tabular}

Abbreviations: $\mathrm{CHN}=$ Chanthaburi, PKK = Prachuap Kriri Khan, SUT = Suratthani, RNG = Ranong, KRB = Krabi 
(6.54 and 16.67 individuals per generation for stocks A and C) (Table 3).

A UPGMA dendrogram constructed from the average unbiased genetic distance between pairs of geographic samples of Thai $P$. pelagicus allocated 5 investigated samples to 2 evolutionarily related groups; Chanthaburi and Suratthani (cluster A) and Prachuap Kriri Khan, Ranong and Krabi (cluster B) (Figure 4).

\section{Discussion}

The estimation and partition of the level of intraspecific genetic variation and population subdivisions are fundamental for establishing rational management of natural resources of commercially important species (Avise 1994; Carvalho and Hauser
1994). Previously, genetic diversity and population structure of $P$. pelagicus in Thailand and Peninsular Malaysia were reported based on AFLP (Klinbunga et al. 2007) and microsatellite polymorphism (Chai et al 2017). Contradictory results on degrees of intraspecific population differentiation in those studies were clarified by the present study.

Theoretically, mitochondrial DNA evolves 5-10 times faster than single copy nuclear DNA (Brown et al. 1979). Polymorphism of $\mathrm{COI}$ sequences has been applied for evaluation of genetic diversity and population differentiation of several crab species, for example, coconut crab Birgus latro (Yorisue et al. 2020), mud crabs Scylla tranquebarica (Sharif et al. 2016) and S. paramamosain (Wang et al. 2020), Chinese mitten crab Eriocheir sinensis (Zhang et al. 2018) and sesarmid
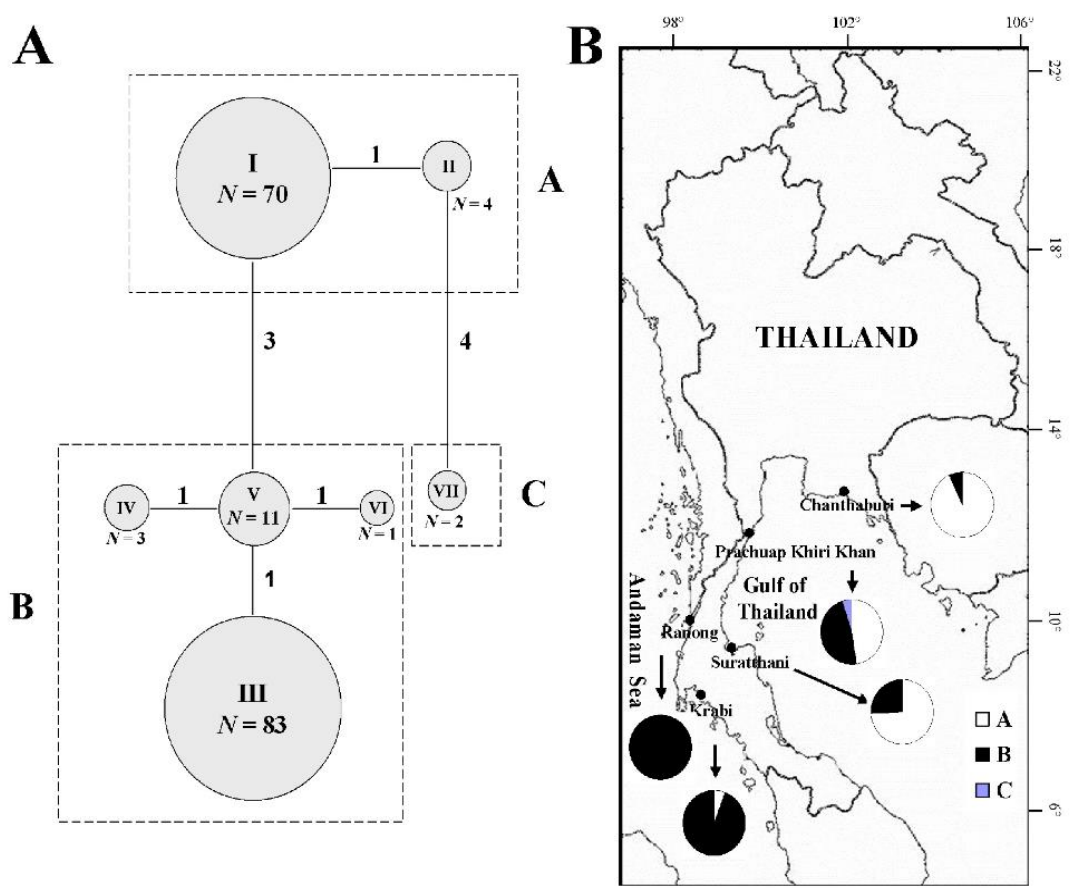

Figure 3. (A) An unrooted maximum parsimony network inferred from nucleotide sequence polymorphism of $P$. pelagicus $C O I$ $\left(\mathrm{PpCOI}_{270}\right)$. Numbers along the branches indicated the numbers of point mutation steps required for interconnections between genotypes. (B) Data from nucleotide sequences and the unrooted maximum parsimony network were used to infer distributions of $\mathrm{COI}$ lineages $\mathrm{A}, \mathrm{B}$ and $\mathrm{C}$ in five geographic samples of $P$. pelagicus.

Table 3. Genetic heterogeneity of five geographic samples of $P$. pelagicus based on SSCP analysis of $P p C O I_{270}$

\begin{tabular}{lcccc}
\hline Geographic & \multicolumn{2}{c}{$F_{\mathrm{ST} \text {-based statistics }}$} & $N_{\mathrm{ef}} m$ & \multicolumn{1}{c}{$\begin{array}{c}\text { Exact test } \\
(P \text {-value })\end{array}$} \\
\cline { 2 - 3 } Sample & \multicolumn{1}{c}{ Theta $(\vartheta)$} & $\chi^{2}$ & & $<0.0001^{* * *}$ \\
CHN-PKK & $0.4282^{*}$ & $29.55^{* * *}$ & 0.67 & $0.0826^{\text {ns }}$ \\
CHN-SUT & $0.0710^{*}$ & $4.54^{*}$ & 6.54 & $<0.0001^{* * *}$ \\
CHN-RNG & $0.9357^{*}$ & $59.88^{* * *}$ & 0.03 & $<0.0001^{* * *}$ \\
CHN-KRB & $0.8407^{*}$ & $53.80^{* * *}$ & 0.09 & $<0.0001^{* * *}$ \\
PKK-SUT & $0.2381^{*}$ & $17.86^{* * *}$ & 1.60 & $<0.0001^{* * *}$ \\
PKK-RNG & $0.3825^{*}$ & $28.69^{* * *}$ & 0.81 & $<0.0001^{* * *}$ \\
PKK-KRB & $0.2518^{*}$ & $18.89^{* * *}$ & 1.49 & $<0.0001^{* * *}$ \\
SUT-RNG & $0.7771^{*}$ & $54.40^{* * *}$ & 0.14 & $<0.0001^{* * *}$ \\
SUT-KRB & $0.6719^{*}$ & $47.03^{* * *}$ & 0.24 & $0.9472^{\text {ns }}$ \\
RNG-KRB & $0.0300^{*}$ & $2.10^{\text {ns }}$ & 16.17 &
\end{tabular}

$\chi^{2}=2 N \vartheta(k-1) ; d f=(s-1)(k-1) ; N$ is the number of individuals used in the analysis, $k$ is the number of alleles per locus, and $s$ is the number of geographic samples. ns $=$ not significant; ${ }^{*}=$ Significant at $\mathrm{P}<0.05 ;{ }^{* *}=\mathrm{P}<0.01 ;{ }^{* * *}=\mathrm{P}<0.001$, respectively. 


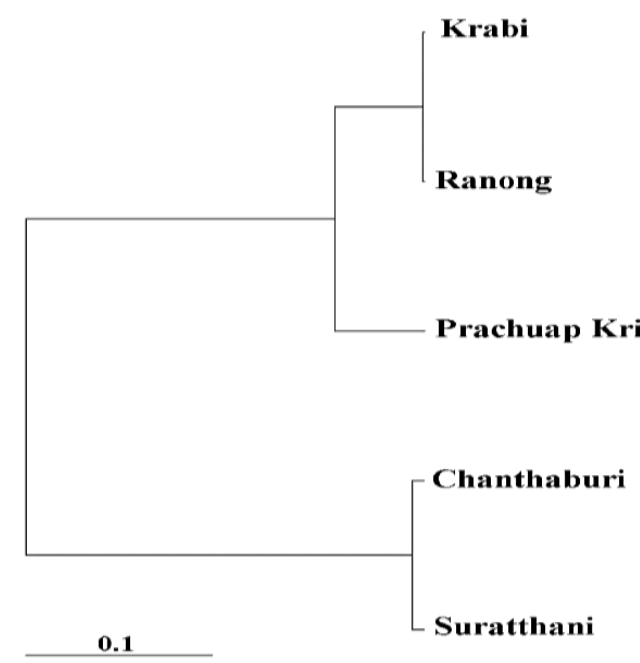

Figure 4. A UPGMA dendrogram indicating relationships of $P$. pelagicus in Thai waters based on genetic distance between pairs of geographic samples. A scale bar indicates genetic distance of 0.1 .

crab Perisesarma bidens (Zhou et al. 2015). In $P$. pelagicus, relative high polymorphism in a $382 \mathrm{bp}$ segment of $\mathrm{COI}$ sequences (53 haplotypes with haplotype and nucleotide diversity of $0.885 \pm 0.0076$ and $0.01448 \pm 0.0078 ; N=400$, respectively) were found in Australian populations (Sezmis 2004). More recently, population genetic differentiation of $P$. pelagicus from southeastern sea of China were also reported based on COI polymorphism (Ren et al 2016). In this study, polymorphic markers were developed from the positive amplification product of mitochondrial $\mathrm{COI}$ ( $\left.\mathrm{PpCOI}_{270}\right)$ and tested against Thai $P$. pelagicus $(N=174)$. Seven SSCP genotypes of $\mathrm{PpCOI}_{270}$ were found in Thai $P$. pelagicus. SSCP bands of mtDNA segments were treated as dominant markers and statistically analyzed.

Technically, SSCP is applied for detection of polymorphism based on conformational analysis but it is sensitive to several analysis parameters such as sizes of the product, temperature during electrophoresis and the residual primers in the PCR products (Chen et al 1995; Cai and Touitou 1993; Li et al. 2003). In the present study, the PCR products of crabs that exhibit different SSCP patterns of $\mathrm{PpCOI}_{270}$ were further sequenced and all examined genotypes could be distinguished by one or a few nucleotide substitutions. This indicated that SSCP analysis is comparably potential but more cost-effective for population genetic studies of $P$. pelagicus comparing to direct DNA sequencing of the $\mathrm{COI}$ gene segment.

Previously, population genetic differentiation of P. trituberculatus from six locations: Changjiang Estuary (CJ), Shengsi Islands (SS), Zhoushan Islands (ZS), Dongtou Islands (DT), Dinghai Bay (DH), and Quanzhou Bay (QZ), in the East China Sea $(N=213)$ was reported based on polymorphism of $\mathrm{COI}$ sequences (787 bp). A total of 27 haplotypes and 21 variable sites were found. Relatively high haplotype diversity $(h=0.787 \pm 0.026)$ but limited nucleotide sequence divergence between haplotypes was observed $(\pi=0.00241 \pm 0.00098)$. Analysis of molecular variance (AMOVA) indicated low degrees of population differentiation $(7.64 \%$ of the variation occurred between populations, $\mathrm{P}<0.01)$. When genetic divergence among haplotypes but not haplotype frequencies were taken into the account, significant genetic differentiation among all examined populations $\left(F_{\mathrm{ST}}=0.03409-0.16748\right)$ of $P$. trituberculatus except between CJ-SS $\left(F_{S T}=-0.00926\right)$ and CJ-ZS $\left(F_{S T}=0.02437\right)$ was found. The moderate female gene flow levels between pairs of populations $\left(N_{\mathrm{ef}} \mathrm{m}=2.5-20.0\right.$ individuals per generation) except between CJ-SS (large number of individuals) were observed (Liu et al. 2009).

Unlike $P$. trituberculatus, common SSCP genotypes I and III of $\mathrm{PpCOI}_{270}$ showed different genotype frequencies distribution between $P$. pelagicus from the Gulf of Thailand and Andaman Sea samples. An unrooted maximum parsimony network inferred from $\mathrm{PpCO}_{270}$ sequences clearly suggested strong genetic differentiation of $P$. pelagicus from different coastal regions (i.e. Andaman and Gulf of Thailand). Apparently, polymorphism of mtDNA provided a prominent figure of population subdivisions of Thai $P$. pelagicus as previously reported in Australian $P$. pelagicus based on COI sequences (Sezmis 2004).

Population genetic studies of Thai $P$. pelagicus using a larger sample size were carried out in this study. Limited gene diversity $(0.0063-0.2847)$ but relatively large genetic distance between pairs of geographic samples of $P$. pelagicus was found based on SSCP analysis (0.0014-0.7247). Larger genetic distance between samples from different coastal regions (0.4243-0.7247) than that between geographic samples within coastal regions (0.0124-0.1926 and 0.0014 for the east and west coast regions) was clearly observed. This circumstance supported strong degrees of genetic differentiation of $P$. pelagicus in Thai waters.

Both adult and juvenile $P$. pelagicus inhabited sheltered benthic coastal environments and females migrate outwards into the open ocean for spawning and return into the estuaries after spawning (Potter et al. 1983 and 1990). The larval stages of $P$. pelagicus last for 
26-45 days (Kangas 2000). On the basis of moderately long planktonic larval stages and high potential mobility during the crab phase, a high gene flow level is expected in this species (Edgar 1990). Typically, degrees of population differentiation (inverse proportion to estimated gene flow levels) are inferred from $F_{\mathrm{ST}}$-based statistics. Theoretically, $F_{\text {ST }}$ estimates can range from 0 to 1 where 0 indicates no genetic divergence (complete sharing of genetic materials) and 1 indicates fixation for alternative alleles (no sharing) between populations (Hartl, 1988). Quantitative guideline for $F_{\text {ST }}$ estimates is that great genetic differentiation is occurred if the value is $>0.25$ (Wright, 1978). In the present study, significant population differentiation among almost pairwise comparisons (F $F_{\text {ST }}$-based statistics, $\vartheta=0.2381-0.9357$ except between Chanthaburi-Prachuap Kriri Khan and Ranong-Krabi) of Thai $P$. pelagicus was observed. This indicated that the gene pool of $P$. pelagicus in Thai waters is not panmictic but differentiated to local genetic populations (stocks). Results in the present study revealed clearer population differentiation of $P$. pelagicus in Thai waters than those previously inferred from a limited sample size analyzed by AFLP (Klinbunga et al. 2007).

Typically, significant genetic differentiation of marine invertebrates in Thai waters was found between the Andaman Sea (west) and Gulf of Thailand (east) but not within the east coastal region. Examples of these species are the giant tiger shrimp, $P$. monodon (Klinbunga et al., 2001), the banana shrimp, P. merguiensis (Hualkasin et al., 2003), the abalone, Haliotis asinina (Tang et al., 2004) and the Asian moon scallop, Amusium pleuronectes (Mahidol et al., 2007). In contrast, strong geographic differentiation between investigated samples located within and/or between coastal areas and low female gene flow levels $\left(N_{\mathrm{ef}} m<1.60\right.$ individuals per generation between different genetic stocks) was found in Thai $P$. pelagicus:

Recently, genetic diversity and differentiation of $P$. pelagicus in different Fishery Management Area (FMA) of Indonesia were reported using $\mathrm{COI}$ sequence polymorphism. Significant genetic differentiation between pairwise comparisons of populations ( $\left.F_{\mathrm{ST}}=0.954 ; \mathrm{P}<0.001\right)$ and the fisheries management areas $\left(F_{\mathrm{ST}}=0.964 ; \quad \mathrm{P}<0.001\right)$ were found. Genetic disconnectivity was observed between populations in a distance of at least $60 \mathrm{~km}$ (Madduppa et al. 2021). Population differentiation at a microgeographic scale found in Indonesian $P$. pelagicus strongly supports results from AFLP (Klinbunga et al. 2007) and SSCP analysis of the $\mathrm{COI}$ gene (this study) for $P$. pelagicus in Thai waters

Genetic differentiation between $P$. pelagicus from the Andaman Sea and the Gulf of Thailand could be explained by a major physical barrier as the main current in the Straits of Malacca moves from the south to the north throughout the year. The major reversals in the monsoon driven surface current systems of the Gulf of Thailand (Dale 1956) may involve in differentiation of
P. pelagicus within the Gulf of Thailand. In addition, the migratory behavior may have promoted degrees of genetic differentiation of $P$. pelagicus in Thai waters. Moreover, seasonal variation on gonad maturation between $P$. pelagicus from different geographic locations was reported (Shields and Wood 1993). This may have promoted the fragmentation of $P$. pelagicus gene pools.

A UPGMA dendrogram constructed from interpopulation genetic distance owing to $\mathrm{PpCOI}_{270}$ polymorphism surprisingly allocated the Prachuap Kriri Khan sample to the west- coast samples (Ranong and Krabi). Biogeographic patterns and phylogenetic analysis of $P$. pelagicus suggested that the Gulf of Thailand samples may experience an ancient separation and might have undergone a recent population expansion afterwards.

The blue swimming crab in Thailand is currently managed as a single stock. On the basis of this study, five $P$. pelagicus samples should be regarded as three distinct genetic stocks (see above). From management points of view, these genetically different stocks should be treated and manage separately. Currently, commercial cultivation of $P$. pelagicus has successfully been developed (Azra and Ikhwanuddin 2015). This would significantly reduce the heavily harvest of natural $P$. pelagicus. The ability to identify high genetic diversity and strong population differentiation of $P$. pelagicus is crucial for selection of appropriate broodstock for cultivation of $P$. pelagicus, comparison on the performance of commercially important traits between different stocks and genetic improvement of $P$. pelagicus. An overexploitation of wild $P$. pelagicus reflected by the occurrence of the increasing proportion of small sizes of captured $P$. pelagicus at present may be compensated by enhancement of natural $P$. pelagicus in Thai waters where local genetic stocks are required as founders.

\section{Ethical Statement}

The experiments were carried out to conform to the protocols for animal care and use of the National Center for Genetic Engineering and Biotechnology (BIOTEC) animal welfare committee.

\section{Funding Information}

The authors received no specific funding for this research.

\section{Authors' Contributions}

BK planed the experiments, carried out genetic diversity studies and wrote the first draft of the manuscript. SP and SJ screened primers for amplification of mitochondrial genes and performed DNA cloning and sequencing. SK supervised the project and edited the manuscript. All authors agree to publish the manuscript. 


\section{Conflict of Interest}

BK, SP, SJ and SK declare that they have no conflict of interest.

\section{Acknowledgments}

We thank National Center for Genetic Engineering and Biotechnology (BIOTEC), National Science and Technology development Agency (NSTDA) for providing facilities.

\section{References}

Altschul, S.F., Gish, W., Miller, W., Myers, E.W., \& Lipman, D.J. (1990). Basic local alignment search tool. Journal of Molecular Biology, 215(3), 403-410. https://doi.org/10.1016/S0022-2836(05)80360-2

Avise, J.C. (1994). Molecular Markers, Natural History and Evolution. Chapman and Hall, New York. http://dx.doi.org/10.1007/978-1-4615-2381-9

Azra, M.N., \& Ikhwanuddin, M. (2015). Larval culture and rearing techniques of commercially important crab, Portunus pelagicus (Linnaeus, 1758): Present status and future prospects. Songklanakarin Journal of Science and Technology, 37 (2), 135-145.

Brown, W.M., George, Jr. M., \& Wilson, A.C. (1979). Rapid evolution of animal mitochondrial DNA. Proceeding of the Natural and Academic Science of United State of America, 76, 1967-1971. https://doi.org/10.1073/pnas.76.4.1967

Bryars, S.R., \& Adams, M. (1999). An allozyme study of the blue swimming crab, Portunus pelagicus (Crustacean: Portunidae), in Australia: stock delineation in southern Australia and evidence for a cryptic species in northern waters. Marine and Freshwater Research, 50, 15-26. https://doi.org/10.1071/MF98075

Cai, Q.Q., \& Touitou, I. (1993). Excess PCR primers may dramatically affect SSCP efficiency. Nucleic Acids Research, 21, 3909-3910. https://doi.org/10.1093/nar/21.16.3909

Carvalho, G.R., \& Hauser, L. (1994). Molecular genetics and the stock concept in fisheries. Reviews in Fish Biology and Fisheries 4, 326-350. https://doi.org/10.1007/97894-011-1218-5_3

Chai, C.J., Esa, Y.B., Ismail, M.F.S., \& Kamarudin, M.S. (2017). Population structure of the blue swimmer crab Portunus pelagicus in coastal areas of Malaysia inferred from microsatellites. Zoological Studies, 56, 26. DOI: 10.6620/ZS.2017.56-26

Chen, X., Baumstark, T., Steger, G., \& Riesner, D. (1995). High resolution SSCP by optimization of the temperature by transverse TGGE. Nucleic Acids Research, 23, 45244525. https://doi.org/10.1093/nar/23.21.4524

Dale, W.L. (1956). Wind and drift currents in the South China Sea. The Malaysian Journal of Tropical Geography, 8, 131.

Dower, W.J., Miller, J.F., \& Ragsdale, C.W. (1988). High efficiency transformation of $E$. coli by high voltage electroporation. Nucleic Acids Research, 16, 6127-6145.

Edgar, G.J. (1990). Predator-prey interactions in seagrass beds II Distribution and diet of the blue manna crab Portunus pelagicus Linnaeus at Cliff Head, Western Australia. Journal of Experimental Marine Biology Ecology, 139, 23 32. https://doi.org/10.1016/0022-0981(90)90035-B

Felsenstein, J. (1993). Phylip (Phylogenetic Inference Package) Version 356c Department of Genetics, University of Washington, Seattle.

Folmer, O., Black, M., Hoeh, W., Lutz, R., \& Vrijenhoek, R. (1994). DNA primers for amplification of mitochondrial cytochrome $\mathrm{c}$ oxidase subunit I from diverse metazoan invertebrates. Molecular Marine Biology and Biotechnology, 3, 294-299.

Hartl, D.L. (1988). A Primer of Population Genetics (2nd ed.). Sinauer Associates, Massachusetts. 305 p.

Hualkasin, W., Sirimontaporn, P., Chotigeat, W., Querci, J., \& Pongdara, A. (2003). Molecular phylogenetic analysis of white prawn species and the existence of two clades in Penaeus merguiensis. Journal of Experimental Marine Biology Ecology, 296, 1-11. https://doi.org/10.1016/S0022-0981(03)00299-5

Kailola, P.J., Williams, M.J., Stewart, P.C., Reichelt, R.E., McNee, A., \& Grieve, C. (1993). Australian Fisheries Resources (Bureau of Resource Sciences, Department of Primary Industries and Energy, and the Fisheries Research and Development Corporation, Canberra, Australia.

Kangas, M.I. (2000). Synopsis of the Biology and Exploitation of the Blue Swimmer Crab, Portunus pelagicus Linnaeus, in Western Australia. Fisheries Western Australia, Perth, Western Australia. Fisheries Research Report (121). 22 pp.

Khamnamtong, B., Klinbunga S., Menasveta P. (2005). Species identification of five penaeid shrimps using PCR-RFLP and SSCP analyses of $16 \mathrm{~S}$ ribosomal DNA. J Biochem Mol Biol 38, 491-499. https://doi.org/10.5483/BMBRep.2005.38.4.491

Klinbunga, S., Khetpu, K., Khamnamtong, B., \& Menasveta P. (2007). Genetic heterogeneity of the blue swimming crab (Portunus pelagicus) in Thailand determined by AFLP analysis. Biochemical Genetics, 45, 725-736. https://doi.org/10.1007/s10528-007-9110-1

Klinbunga, S., Praipue, P., Khamnamtong, N., Tassanakajon, A., Jarayabhan, P., Hirono, I., Aoki, T., Menaseveta, P. (2003). Genetic diversity and molecular markers of the tropical abalone (Haliotis asinina) in Thailand. Marine Biotechnology, 5, 505-517. https://doi.org/10.1007/s10126-002-0108-8

Klinbunga, S., Siludjai, D., Wudthijinda, W., Tassanakajon, A., Jarayabhand, P., \& Menasveta, P. (2001). Genetic heterogeneity of the giant tiger shrimp (Penaeus monodon) in Thailand revealed by RAPD and mitochondrial DNA RFLP analyses. Marine Biotechnology 3, 428-438. https://doi.org/10.1007/s10126-001-0055-9

Klinbunga, S., Sodsuk, S., Penman, D.J., \& McAndrew, B.J. (1996). An improved protocol for total DNA isolation and visualisation of mtDNA-RFLP(s) in tiger prawn, Penaeus monodon. Thai Journal of Aquatic Science 3, 36-41.

Lai, J.C.Y, Ng, P.K.L., \& Davie, P.J.F. (2010). A Revision of the Portunus pelagicus (Linnaeus, 1758) species complex (Crustacea: Brachyura: Portunidae) with the recognition of four species. The Raffles Bulletin of Zoology, 58, 199237. 
Li, W., Gao, F., Liang, J., Li, C., Zhang, H., Tang, Z. et al. (2003). Estimation of the optimal electrophoretic temperature of DNA single-strand conformation polymorphism by DNA base composition. Electrophoresis, 24, 2283-2289. https://doi.org/10.1002/elps.200305506

Liu, Y., Liu, R., Ye, L, Liang, J., Xuan, F., \& Xu, Q. (2009). Genetic differentiation between populations of swimming crab Portunus trituberculatus along the coastal waters of the East China Sea. Hydrobiologia, 61, 125-137. https://doi.org/10.1007/s10750-008-9570-2

Mahidol, C., Na-Nakorn, U., Sukmanomon, S., Taniguchi, N., \& Nguyen, T.T.T. (2007). Mitochondrial DNA diversity of the Asian moon scallop, Amusium pleuronectes (Pectinidae), in Thailand. Marine Biotechnology, 9(3), 352-359. https://doi.org/10.1007/s10126-006-6137-y

Miller, M.P. (1997). Tools for population genetic analyses TFPGA 13: A window program for the analysis of allozyme and molecular population genetic data. Department of Biological Sciences, Northern Arozona University.

Madduppa, H., Martaulina, R., Zairion, Z., Renjani, R.M., Kawaroe, M., Anggraini, N.P., Subhan, B., Verawati, I., \& San, L.M.I. (2021). Genetic population subdivision of the blue swimming crab (Portunus pelagicus) across Indonesia inferred from mitochondrial DNA: Implication to sustainable fishery. PLoS ONE, 16(2), e0240951. https://doi.org/10.1371/journal.pone.0240951

Nei, M. (1987). Molecular Evolutionary Genetics. Columbia University Press, New York. https://doi.org/10.1002/ajpa.1330750317

Nei, M. (1978). Estimation of average heterozygosity and genetic distance from a small number of individuals. Genetics, 89(3), 583-590.

Orita, M., Iwahana, H., Kanazawa, H., Hayashi, K., \& Sekiya, T. (1989). Detection of polymorphisms of human DNA by gel electrophoresis as single-strand conformation polymorphisms. Proceedings of the Natural Academic Science of United State of America, 86, 2766-2770. https://doi.org/10.1073/pnas.86.8.2766

Potter, I.C., Chrysta, P.J., Loneragan, N.R. (1983). The biology of the blue manna crab Portunus pelagicus in an Australian estuary. Mar Biol 78, 75-85. https://doi.org/10.1007/BF00392974

Potter, I.C., Sumpton, W.D., Smith, G.S. (1991). Movement, fishing sector impact, and factors affecting the recapture rate of tagged sand crabs, Portunus pelagicus (L) in Moreton Bay, Queensland. Australian Journal of Marine and Freshwater Research 42, 751-760. https://doi.org/10.1071/MF9910751

Ren, G.J., Miao, G.D., Ma, C.Y., Lu, J.X., Yang, X.L., \& Ma, H.Y. (2016). Genetic structure and historical demography of the blue swimming crab (Portunus pelagicus) from southeastern sea of China based on mitochondrial $\mathrm{COI}$ gene. Mitochondr DNA.

https://doi.org/10.1080/24701394.2016.1261855

Sambrook, J., \& Russell, D.W. (2001). Molecular Cloning: A Laboratory Manual, third ed. Cold Spring Harbor Laboratory Press, New York.

Sharif, N.A.M., Kahar, N.A.S., Rodrigues, K., Ransangan, J., \& Kian, A.Y.S. (2016). Genetic diversity of mud crabs, Scylla tranquebarica in Sabah, Malaysia based on Cytochrome
C Oxidase (COI) gene sequence. Songklanakarin Journal of Science and Technology, 38(4), 365-372.

Sezmis, E. (2004). The Population Genetic Structure of Portunus pelagicus in Australian Waters. PhD thesis, Murdoch University, Perth, Australia.

Shields, J.D., \& Wood, F.E.I. (1993). Impact of parasites on the reproduction and fecundity of the blue sand crab Portunus pelagicus from Moreton Bay, Australia. Marine Ecology Progress Series, 92, 159-170.

https://doi.org/10.3354/meps092159

Sihanuntavong, D., Sittipraneed, S., \& Klinbunga, S. (1999). Mitochondrial DNA diversity and population structure of the honey bee, Apis cerana, in Thailand. Journal of Apiculture Research, 38, 211-219. https://doi.org/10.1080/00218839.1999.11101012

Small, M.P., \& Chapman, R.W. (1997). Intraspecific variation in the $16 \mathrm{~S}$ ribosomal gene of Crassostrea virginica. Molecular Marine Biology and Biotechnology, 6, 189-196.

Sneath, P.H.A. \& Sokal, R.R. (1973). Numerical Taxonomy. WH Freeman and Co, San Francisco. https://doi.org/10.2307/2412767

Tang, S., Tassanakajon, A. Klinbunga, S., Jarayabhand, P., \& Menasveta, P. (2004). Population structure of tropical abalone (Haliotis asinina) in coastal waters of Thailand determined using microsatellite markers. Marine Biotechnology, 6, 604-611. https://doi.org/10.1007/s10126-004-2300-5

Thompson, J.D., Higgins, D.G., \& Gibson, T.J. (1994). CLUSTAL W: improving the sensitivity of progressive multiple sequence weighting, position-specific gap penalties and weight metric choices. Nucleic Acids Research, 22, 4673-4680. https://doi.org/10.1093/nar/22.22.4673

Wang, W., Ma, C., Chen, W., Jin, Z., Zhao, M., Zhang, F., Liu, Z., \& $\mathrm{Ma}$, L. (2020). Population genetic diversity of mud crab (Scylla paramamosain) from southeast coastal regions of China based on mitochondrial COI gene sequence. Gene, 751, 144763. https://doi.org/10.1016/j.gene.2020.144763

Weir, B.S., \& Cockerham, C.C. (1984). Estimating F-statistics for the analysis of population structure. Evolution, 38, 13581370. https://doi.org/10.2307/2408641

Wright, S. (1978). Evolution and the Genetics of Populations. Vol. 4, Variability within and among Natural Populations. Univ. Chicago Press, Chicago. 580 p.

Yap, E.S., Sezmis, E., Chapin, J.A., Potter, I.C., \& Spencer, P.B.S. (2002). Isolation and characterization of microsatellite loci in Portunus pelagicus (Crustacea: Portunidae). Molecular Ecology Notes, 2, 30-32. https://doi.org/10.1046/j.1471-8286.2002.00136.x

Yorisue, T., Iguchi, A., Yasuda, N., Yoshioka, Y., Sato, T., \& Fujita, Y. (2020). Evaluating the effect of overharvesting on genetic diversity and genetic population structure of the coconut crab. Scientific Reports, 10, 10026. https://doi.org/10.1038/s41598-020-66712-4

Zhang, C., Li, Q., Wu, X., Lin, Q., \& Cheng, Y. (2018). Genetic diversity and genetic structure of farmed and wild Chinese mitten crab (Eriocheir sinensis) populations from three major basins by mitochondrial DNA COI and $C y t b$ gene sequences. Mitochondrial DNA Part A DNA Mapping, Sequencing, and Analysis, 29(7), 1081-1089. https://doi.org/10.1080/24701394.2017.1404048

Zhou, H., Xu, J., Yang, M., Wu, B., Yan, B., \& Xiong, Y. (2015). Population genetic diversity of sesarmid crab (Perisesarma bidens) in China based on mitochondrial DNA. Mitochondrial DNA, 27(5), 1-8. https://doi.org/10.3109/19401736.2015.1015002 